\title{
Zoonotic and Animal Vector Mediated Encephalitides
}

\author{
Colleen Mikelson and Sean Richards \\ University of Tennessee Chattanooga \\ United States of America
}

\section{Introduction}

When discussing human diseases in general, the majority (61\%) of them are zoonotic, or are able to be transferred between animals and humans (Taylor et al., 2001), either through the bite of an arthropod, exposure to the pathogen through direction contact with animal products (urine, feces, milk, afterbirth) or when humans are a part of the pathogen's life cycle directly. In regard to diseases that are considered emerging, $75 \%$ of them are zoonotic (Taylor et al., 2001), which places more weight on the study of these pathogens and their evolution in order to better understand the risk of infection to a new host (Alexander and Day, 2010). This chapter is designed to give the reader an overview of the wide array of pathogenic etiologies, whether viral, bacterial or parasitic, that have the potential to develop into encephalitis, though in some cases, this is a rare side effect, or limited to specific groups (i.e., immunecompromised individuals). Of these diseases, all have a life cycle intimately connected with an animal vector or host in some way. Some disorders are very well known and studied as a means of vector transmitted encephalitis (e.g., Eastern Equine Encephalitis), while others are just emerging as serious health risks associated with encephalitic symptoms (e.g., Chandipura Virus Encephalitis, Nipah and Henipa virus).

\section{Viral related diseases}

Viral infections are important in the induction of encephalitis. Arboviruses are transmitted by arthropods (e.g., mosquitoes, ticks, sand flies) and are maintained through biological transmission between a vertebrate host (Kuno \& Chang, 2005). Biological transmission of such a pathogen involves several factors (Reviewed by Scott, 1988). The virus must be able to reproduce in both the arthropod and vertebrate host, then be able to produce a high enough viral titer in the blood of the vertebrate to be passed back to the vector Reviewed by Scott, 1988). It is well known that RNA viruses tend to have a high mutation rate because of unfaithful replication in host cells, among other things (Domingo, 1997). However, to maintain a relationship with both vertebrate and arthropod vectors, observed mutation rates are reduced, as is with New World Alpha viruses (Weaver et al., 1991). When selective pressures are applied to the virus between two alternating hosts, the virus population responds with adaptations fit for both environments in order to optimize suitability in a dual host system (Weaver et al., 1999; Cooper \& Scott, 2001). 
These viruses can be maintained in either a zoonotic or an epizootic cycle; the former involving endemic birds, rodents or non-human primates as reservoir hosts (Weaver et al., 1999), the latter is involved in epidemics or outbreaks of the disease in livestock or humans. Reservoir hosts are abundant and readily available in the vector habitat, are attractive to the vector as a potential host, and allow for viral replication sufficient to infect previously uninfected vectors, but low enough to prevent a fatal infection (Scott, 1988). Epidemics of these diseases arise when efficient bridge vectors are able to pass on the virus to new, and potentially dead-ended, hosts (e.g. humans) (Weaver et al., 1999; Armstrong \& Theodore, 2010). Also critical to the success of viral transmission is the vector competence, or the ability of the vector to successfully infect a new host with the virus; moreover the vector is able to become infected with the pathogen from wild caught samples, able to efficiently bite the host, and the presence of the virus detectable in wild-caught vertebrate samples (Sudia et al., 1969). But these viruses are not limited to arthropod transfer. Other viruses are linked to bats and other wild animals to ensure their survival. The viral families included in this review are Arenaviridae, Bunyaviridae, Flaviviridae, Paramyxoviridae, Rhabdoviridae and Togaviridae.

\subsection{Family Arenaviridae: Lymphocytic Choriomeningitis (LCM) Virus}

The Arenaviridae are a family of viruses whose members are generally associated with rodent-transmitted disease in humans. The Lymphocytic Choriomeningitis (LCM) Virus is released in mouse urine and feces, as well as nasal secretions, saliva, milk and semen. The infectious route can be through direct contact with infected items or inhalation of aerosolized virus particles. Hamsters and guinea pigs are other rodent that can be infected (Barton \& Mets, 2001). Meningoencephalitis was reported by Barton and Hyndman (2000) after infection with Lymphocytic Choriomeningitis Virus. Maternal infection has been shown to produce teratogenic effects (Larsen et al., 1993; Barton et al., 1995; Bonthius \& Perlman, 2007).

\subsection{Bunyaviridae Family: Californian Serogroup, Toscana Virus and Rift Valley Fever Virus}

\subsubsection{Californian Serogroup: Jamestown Canyon and La Cross Virus}

The Jamestown Canyon Virus is endemic to Michigan and is primarily transmitted by Aedes stimulans (Woodland mosquito) with the white tail deer as its preferred host, and is able to pass the virus transovarially (Boromisa \& Grimstad, 1986; Zamparo et al., 1997). In one study, $27 \%$ of the population showed specific neutralizing antibody to the virus (Grimstad et al., 1986), however this virus has been detected along the east coast of the U.S. as well (Zamparo et al., 1997). Fatal cases of encephalitis have been reported (Grimstad et al., 1982). The La Cross virus is transmitted through Ochlerotatus triseriatus (Eastern treehole mosquito) as well as Ae. albopictus (Tiger mosquito) in Tennessee (Erwin et al., 2002) with small rodent hosts primarily in the Midwest and southern Appalachian region (Georgiev, 2009). Numerous outbreaks of the virus have been reported (Rust et al., 1999; McJunkin et al., 2001).

\subsubsection{Toscana Virus}

The Toscana virus (TOSV) (genus Phlebovirus), is located primarily in the Mediterranean. It was first isolated in Italy, with subsequent cases in Spain, Portugal, France, Greece, Portugal and Germany and Cyprus (Charrel et al., 2005). The sandfly, Phlebotomus perniciosus is the primary vector and reservoir, with no connection yet as to a specific mammalian or avian host (Charrel et al., 2005). Occupational exposure to sandfly habitat correlated with 
seroprevalence of the virus, with up to $77.2 \%$ of the forestry workers testing positive for the antibody (Valassina et al., 2003). This virus is responsible for encephalitis complications, without accompanying meningitis (Dionisio et al., 2001; Valassina et al., 2003).

\subsubsection{Rift Valley Fever Virus}

Rift Valley Fever Virus (RVFV) is named from the region of Kenya from which it was first isolated (Daubney et al., 1931). A wide range of mosquito genera have been shown to maintain the enzoonic cycle (e.g., Aedes, Ochlerotatus, Stegomyia, Anopheles, Culex, Neomelaniconion, Eretmapodites), with Aedes vexans and Culex erraticus showing successful transmission to other animals to serve as bridge vectors (as reviewed by Pfeffer and Dobler (2010)). Infection in pregnant ruminants induces abortion at all stages of pregnancy to the magnitude that this event is referred to as an "abortion storm" (Kasari et al., 2008). Aborted fetuses, birthing material and body fluids of infected animals carry high viral loads and contact with these materials is a possible pathway for human infection (Pepin et al., 2010). Encephalitis was reported in outbreaks in Egypt and Saudi Arabia (Laughlin et al., 1979; Madani et al., 2003).

\subsection{Flaviviridae Family: Japanese Encephalitis Virus Serogroup, Tick Borne Encephalitis and Dengue Fever Encephalitis}

\subsubsection{Japanese Encephalitis Virus Serogroup: Japanese, St. Louis, and Australian} Encephalitis Virus and West Nile Virus

With over 50,000 cases occurring each year, the Japanese Encephalitis Virus (JEV) is responsible for the most cases of epidemic encephalitis worldwide (Weaver \& Barrett, 2004). Pigs are suspected to be the main amplification host for the virus involving human infection due to their proximity to human habitation. Ardeid birds (e.g., herons and egrets) serve as the natural hosts. The mosquito vector, Culex tritaeniorhynchus, feeds on all hosts (birds, pigs and humans) and finds suitable habitat in the flooded rice paddies of Southeast Asia. Humans and horses are susceptible, but are considered dead end hosts (reviewed by Pfeffer and Dobler (2010)).

The primary vectors for the St. Louis Encephalitis Virus (SLEV) are Cx. Pipiens and Cx. Quinquefasciatus, in the western U.S., Cx. Tarsalis, and Cx. Nigripalpus in Florida. Various birds serve as reservoirs (McLean et al., 1993; Georgiev, 2009). Outbreaks have been reported in almost every American state, along with Canada, and Central and South America (Calisher, 1994). Evidence suggests that SLEV was introduced into North America from South America and is locally circulated. Sequence comparisons from various strains show that the overall genome sequence is more conserved than other members of the Japanese serogroup (May et al., 2008). Basal diversification northward is estimated to have initiated around 177-247 years ago (Baillie et al., 2008). Vertical transmission of the St. Louis virus was studied by Flores et al. (2010). Vertical transmission is used as an overwinter mechanism for Culex quinquefasciatus in the temperate areas of Argentina, where St. Louis encephalitis is endemic. Lab studies confirmed that larva and adults both are capable of acquiring the virus.

Australian Encephalitis can be caused by two viral agents, the Murray Valley Encephalitis Virus or Kunjin Virus, which are distributed in both Australia and Papua New Guinea. In Western Australia, the virus is monitored through the testing of serum from sentinel chickens (Hall et al., 1995). The virus is focused in the western part of the country, linked to the growth of the primary mosquito vector, Culex annulirostris. This habitat also supports 
important reservoir species, wading birds, of which, the rufous night heron (Nycticorax caledonicus) is of particular importance (as reviewed by Russell et al. (2000)). The last outbreak of the disease was in 1974; 22 patients were admitted, with four deaths reported, but eleven recovered without lasting effects (Bennett, 1976). In 2000, the wet season brought record breaking rainfall, increasing the breeding ground for the vector which resulted in nine cases of encephalitis in Western Australia. A survey of sentinel chickens showed that the virus was moving southward and human infections were outside a previously determined enzootic area. New monitoring boundaries were established for the disease after this outbreak occurred (Broom et al., 2002).

West Nile Virus (WNV) was first isolated from the West Nile region of Uganda, with a relatively recent emergence of the virus in the U.S., first infecting several birds in a New York City zoo, which displayed meningoencephalitis and myocarditis. From these samples, nationwide awareness of the virus was sparked and linked to extensive bird mortality in the U.S. (Briese et al., 1999; Hayes, 2001; McLean et al., 2001). Further investigation using antigenic mapping and phylogenetic analysis linked the origin of the virus to Israel, isolated from a deceased goose (Lanciotti et al., 1999). The cycle is maintained between birds, mainly passerine, and Culex sp., which serves as the predominate vector (as reviewed by Pfeffer and Dobler (2010)). Central nervous system infection can result in encephalitic onset in approximately $1 \%$ of the patients (Solomon et al., 2003).

\subsubsection{Tick Borne Encephalitis and Powassan virus}

There are three main groups of Tick Borne Encephalitis Virus (TBEV): Western (Central, eastern and northern Europe), Siberian (Russia, eastern Europe), Far-Eastern (Eurasia, Asia and Japan) and one main group of Powassan virus (North America, Far eastern Russia), all of which have been reported to be the causative agent in meningoencephalitis (reviewed by Günther \& Haglund (2005)). The virus is transmitted by Ixodes ticks (Ix. Ricinus and Ix. Persulcatu) and small rodents (Myodes and Apodemus) (Pfeffer \& Dobler, 2010). Because of a tick's extended feeding time on a host, high viral titers in the parasite's saliva glands are not necessary for successful pathogen transmission and enable another means of infecting ticks attached in the same area. Saliva-assisted transmission (SAT) occurs between ticks of close proximity by pharmacological active molecules released into the wound site, which facilitates co-feeding, allowing for passage of the virus from tick to tick in close proximity to each other (Kaufman, 2010). Human and domesticated animals are not considered to be reservoirs, so passage from tick to tick is an important part of the pathogenic cycle (Pfeffer \& Dobler, 2010). The Powassan Virus, originally known as Deer Tick Virus, has had several outbreaks, mainly in North America (New York, Ontario and Quebec) that have lead to encephalitic onset of those infected (Gholam et al., 1999). This virus has three distinct enzootic cycles: $I x$. cookei and woodchucks and mustelids, Ix. marxi and squirrels, and Ix. Scapularis and white-footed mice (Ebel, 2009).

\subsubsection{Dengue Fever Encephalitis}

There are four serotypes of the Dengue Fever Virus (DEN-1-4). In this lifecycle, humans serve as the amplifying host and are able to re-infect new female mosquitoes (Ae. aegypti in urban areas, Ae. Albopictus in suburban/rural areas) (Becker et al., 2010). Central nervous system involvement is suspected to be responsible for potential encephalitic onset (Lum et al., 1996; Muzaffar et al., 2006). The wide geographical breath of this disease puts approximately 2.5 billion people as risk of disease contraction (WHO, 2009). 


\subsection{Paramyxoviridae Family: Hendra and Nipah Viruses}

Both Hendra (formerly equine morbillivirus) and Nipah are emerging encephalitic viruses. Though first associated with equine infection in 1994, other human fatal human cases followed in Australia (O'Sullivan et al., 1997). Flying foxes or fruit bats (genus Pteropus) serve as the virus reservoir (Halpin et al., 2000), while transmission to domestic animals (horses, pigs, cows) allows for virus amplification and a pathway for human infection. Domesticated animals are suspected to become infected with the virus after contact with bat urine, discarded fruit or birthing material (as reviewed by Wang et al. (2008)). Bats themselves transfer the virus both horizontally through feces, urine or saliva (Plowright et al., 2008) and can be passed through the placenta (Williamson et al., 2000).

Nipah virus is another highly fatal paramyxovirus transmitted by bats with a domesticated livestock amplification host (Harcourt et al., 2000; Epstein et al., 2006). The first outbreak was among pig farmers in Malaysia (Mohd Nor et al., 2000), and further south into Singapore (Paton et al., 1999), in 1998-1999. The Malaysia outbreak showed no spill over from its pig farming source, with a morality rate of $40 \%$ of infected people. The second, more severe outbreak was in Bandladesh, with a mortality rate of $75 \%$. This strain of Nipah was shown to be different than the Malaysian strain, and characterized by its lack of amplifying host (Epstein et al., 2006) and ability to be transferred from human to human, supported by in increased risk of infection when cohabitating with an infected individual (Vincent P. Hsu, 2004). Pig to pig transmission is through inhalation of aerosolized virus particles and is highly infectious (Mohd Nor et al., 2000). Similar to Hendra, partially eaten fruit from an infected bat is a possible mechanism to initial infection in pigs, due to significant viral presence in bat saliva, or through contact with bat urine (Chua et al., 2002). The farm where the first outbreak occurred had numerous fruit trees, a major attractant for the bats (Chua et al., 2002). More recent studies looked at date palm sap, commonly consumed by humans and bats. Harvesting season coincided with the Banglash outbreak, so Salah et al. (2011) experiment with physical barriers to restrict bat consumption and help curb the spillover into humans facilitated by consumption of contaminated date palm sap.

\subsection{Rhabdoviridae Family: Rabies and Chandipura virus and Australian bat lyssavirus (ABLV)}

The rabies virus (genus Lyssavirus) is still an important cause of fatal cases of encephalitis (Mallewa et al., 2007). The most likely route for human infection is through bite wound, where the virus contaminated saliva enters into the bloodstream of the new host. The virus can also be obtained through mucous membrane passage or virus inhalation from batinfested caves. The only documented human-human transfer was via corneal transplant (as reviewed by Krebs et al. (1995)). Rabies infections have largely been brought under control in developing countries through the vaccination of domestic dogs, though dogs bites in developing countries is the main pathway of human infection. Raccoons (Smith et al., 1995), as well as bats (silver-haired and eastern pipistrelle) are the most common animals to be infected in the U.S., with bats presenting more cryptic cases of rabies infections due to a lack of obvious bite wounds (Messenger et al., 2002). Mutations of the virus through serial passes through hosts can create quasispecies, suggesting a mechanism to the accommodation to a novel hosts (Morimoto et al., 1998; Kissi et al., 1999). Bourhy et al. (1999) showed, through an analysis of European strains of the virus, local genetic differentiation is taking place, facilitated by physical barriers. Evidence suggests substitution rates in the nucleoprotein gene is related to its infection adaption in bats (Hughes et al., 2005). 
One of the lesser known viral encephalides is the Chandipura virus (genus Vesiculovirus). Even though it is not well reported in the literature (Van Ranst, 2004), it was responsible for considerable encephalitic outbreaks in India in the last decade, in 2003 and again in 2007 (Rao et al., 2004; Narasimha Rao et al., 2008; Gurav et al., 2010). Viral transmission is through Phlebotomid sandflies (genus Sergentomyia) (Mavale et al., 2005) and is mainly found in India, but has also been isolated from sand flies in West Africa (Fontenille et al., 1994). The potential and need for further research in this emerging human pathogen is great (Potharaju \& Potharaju, 2006).

Australian bat lyssavirus (ABLV) is another encephalitic virus found in Pteropid bats, and as the name implies, this rabies-like virus is found in Australia (Warrilow et al., 2002). Two fatal encephalitis cases were confirmed to be caused by ABLV. The first in 1996 from an animal handler (Allworth et al., 1996); the second had been bitten by a flying fox (Hanna et al., 2000). Serologic testing done in the Philippines suggest that this virus is also present there, though no active infections were found in the bats sampled (Arguin et al., 2007).

\subsection{Togaviridae Family: Old and New World Alpha Viruses}

Alpha viruses have been delineated as either New or Old World, depending on their geographical distribution; New World being primarily in the Americas, while Old World is in the Africa, Europe, Asia and Australia (Paredes et al., 2005). Besides their spatial differences, these viruses typically manifest different disease characteristics. Old World infections usually are more benign, with rash and arthritic symptoms, while the New World alpha virus infections can result in febrile disease with possible encephalitis onset (Paredes et al., 2005). However, several Old World viruses have showed to develop into encephalitis, with Chikungunya virus (CHIKV) and a variant of Semliki Forest virus (SFV) as such examples.

\subsubsection{Old World: Chikungunya, Me Tri and Ross River Virus}

Chikungunya Virus (CHIKV) was first isolated in Africa, with outbreaks reported in the Congo and Senegal (Diallo et al., 1999; Pastorino et al., 2004). CHIKV is transmitted by gallery forest mosquitoes, from wild forest primates and rodents (genus Aedes) (Diallo et al., 1999). Outbreaks of the virus in La Réunion, an island in the south Pacific followed by wide spread infection in India, Sri Lanka and Indonesia, resulted in considerable central nervous system involvement, including encephalitis (Rampal et al., 2007; Robin et al., 2008; Rajapakse et al., 2010), with human-human transmission facilitated mainly by Aedes aegypti in urban areas (Lahariya \& Pradhan, 2006). A similar Old World Virus that has shown encephalitis onset is Me Tri virus, first isolated from Culex tritaeniorhynchus mosquitoes in the Me Tri Village of North Vietnam (Ha et al., 1995), though later it was classified as a Semliki Forest Virus (SFV) variant that had undergone homologous recombination, though this is the first variant of SFV outside of Africa (Tan et al., 2008). Ross River Virus is also an Old World alpha virus, suspect of encephalitic onset, though causation is lacking as to whether or not those isolated incidents were truly caused by Ross River virus (Harley et al., 2001).

\subsubsection{New World Alpha Viruses: Eastern, Western and Venezuelan Equine Encephalitis Virus}

Eastern Equine Encephalitis Virus (EEEV) is primarily found the Atlantic and Gulf Coast states, but cases have been reported further north into Canada, and into South America (Argentina and Peru) (Hansen \& Docherty, 1999). Passerine birds serve as the amplification 
host for the virus (Chamberlain et al., 1954; Komar et al., 1999) and Culiseta melanura, a mainly ornithophic mosquito, maintains the lifecycle in endemic areas between bird hosts, though other genera have be able to become infected (Armstrong \& Theodore, 2010). The virus starts its replication in the mid-gut epithelial cells and maintains a persistent infection in the mosquito, eventually reaching the salivary glands to ensure viral transfer (Georgiev, 2009). Mosquito with a wider range of hosts (Coquillettidia, Culex, Ochlerotatus, Aedes, spp.) serve to infect dead-end hosts (humans and horses) (Pfeffer \& Dobler, 2010), with often fatal consequences for both (Pfeffer \& Dobler, 2010).

Western Equine Encephalitis virus undergoes a similar endemic cycle in birds as EEEV does, with Culex tarsalis as the maintaining mosquito vector, although there is a cycle between rodents and Ochlerotatus melanimon in South America (Pfeffer \& Dobler, 2010). WEEV can be found in North, South and Central America (Weaver et al., 1997), though C. tarsalis is well sustained in the Western U.S. in areas of agriculture and stream drainages (Zacks \& Paessler, 2010).

Unlike the previous alpha viruses, the Venezuelan Equine Encephalitis Virus (VEEV) is maintained mainly in a mosquito/rodent cycle and amplification and further amplification is seen in horses and humans (Pfeffer \& Dobler, 2010). C. Melanoconion serves as the enzootic strain vector among rodent hosts. The key to epidemic/epizootic transmission is through a the selection of the E2 envelope protein mutation of ID or IE subtypes (Pfeffer \& Dobler, 2010), from which the IAB and IC subtypes emerge, and go on to infect equines and humans through Ochlerotatus taeniorhynchus (Georgiev, 2009). For additional details of the VEEV virus, mosquito vectors (both enzoonic and epizoonic), as well as the transmission cycle, please see the review by Weaver et al. (2004).

\section{Bacterial Encephalitides}

\subsection{Brucellosis: Brucella}

There are six 'classical' strains of Brucella genus, found in specific animals, Brucella ovis, Brucella canis, Brucella neotomae, Brucella abortus, Brucella melitensis, and Brucella suis (Moreno et al., 2002), with the latter three strains capable of infecting humans and human producing brucellosis (de Jong et al., 2010). These three strains are also able to infect reticuloendothelial tissues as well as reproductive tract cells, which results in abortions or sterility (de Jong et al., 2010). Neurological affects can manifest into Neurobrucellosis, with meningoencephalitis as a potential complication, though a rare occurrence among those affected (Shakir et al., 1987; Al Deeb et al., 1989). Brucella has also been detected in terrestrial wildlife populations (Godfroid, 2002), as well as marine mammals (Foster et al., 2002) and has been shown to jump from wildlife reservoirs to domestic herds in close proximity to each other. The study done by BejaPereira et al. (2009) showed that elk were the origin species for the Brucella outbreak in cattle herds in the greater Yellowstone area. For the greater population, human infection is usually caused by consumption of dairy products contaminated with the bacterium (De Massis et al., 2005). The risk of infection increases with animal contact, especially around periods of perturbation, which puts farm workers/ranchers, veterinarians and meat-packing employers at greater risk of infection (Seleem, Boyle et al. 2010).

\subsection{Leptospirosis: Leptospira}

Leptospirosis is caused by two species of Leptospira; L. interrogans and L. borgpetersenii. L. interrogans is effective in surviving in the environment, while L. borgpetersenii is host 
dependent. Genome analysis between these two pathogenic strains showed that the host dependent strain had approximately $700 \mathrm{bp}$ smaller genome and overall lower gene density than L. interrogans, and an obligate host to host transmission cycle (Bulach et al., 2006). Leptospires reproduce in the kidneys are shed through the urine of infected animals. Disease contraction occurs with exposure to urine and pathways to the body include skin abrasions, passage of the mucous membranes or consumption of contaminated water. Rodents are asymptomatic and are reservoirs for the bacterium, which facilitates and maintains infection in domesticated animals, as well as from passage to animal to animal in herds (Antony, 1996; Ko et al., 2009). A review of global occurrences of leptospirosis was done by Pappas et al. (2008), which showed the endemic areas of the world were mainly located in the Caribbean and Central and South America, as well as in Southeast Asia and Oceania, though the authors reported that it is probably an incomplete list due to lack of data from developing countries and unreliable reports from other parts of the world. The human leucocyte- like antigen DQ-6 (HLA-DQ6) polymorphism in has showed an increased risk of leptospirosis via consumption of contaminated water (Lingappa et al., 2004). Encephalitis onset has been reported (Dimopoulou et al., 2002).

\subsection{Listeriosis: Listeria monocytogenes}

Human Listeria infections most often occur because of consumption of contaminated food products, but Listeria is also shed in the feces of infected livestock. When the manure is spread on crop fields, food, soil and water contamination becomes an issue (Swaminathan \& Gerner-Smidt, 2007). This pathogen is capable of living in a wide range conditions, tolerating in both an extensive temperature and $\mathrm{pH}$ range $(0.5-45 \mathrm{C}$, $\mathrm{pH} 4.3-9.8)$ (Gandhi \& Chikindas, 2007). L. monocytogenes is capable of infecting a variety of hosts (Roberts \& Wiedmann, 2003), but mainly reported in livestock (Low \& Donachie, 1997). Human encephalitic cases have been reported (Johnson \& Colley, 1969; Armstrong \& Fung, 1993). The genetic changes seen in two lineages of L. monocytogenes, lineage II, the more environmentally resistant strain, and lineage I, the more host adapted lineage, was found to be in the cell wall and membrane biogenesis and motility-related genes (Orsi et al., 2008).

\subsection{Lyme's Disease: Borrelia burgdorferi}

The Lyme's disease (Lyme borreliosis) spirochete (Borrelia burgdorferi) is spread through ixodid ticks. Humans make up a small portion of bloodmeals, but can become infected through bites of Ixodes dammini/scapularis in the eastern U.S., Ixodes pacificus in the western United States and Ixodes ricinus in Europe. Ixodes dammini's primary host is the white-footed mouse, Peromyscus eucopus, and the white-tailed deer, Odocoileus virginianus. In the western US, fence lizards (Sceloporus occidentalis) and Columbian black-tailed deer are reservoirs (as reviewed by Lane et al. (1991)). A study done in California found that woodrats serve as the reservoir hosts while Ixodes neotomae maintains the spirochete, though it does not facilitate human transfer (Brown \& Lane, 1992). After the spirochete is ingested in the initial bloodmeal, protective outer surface proteins are produced as a buffer from digestion mechanisms in the tick's midgut. There it will stay until the tick molts and engages in its second bloodmeal. Feeding triggers spirochete reproduction, followed by migration to the salivary glands, allowing for host transfer (Spielman et al., 1987). The bacterium enter the host's skin and migrate out from the bite site and create the characteristic bull's eye mark of infection (Steere, 2001). A small portion of patients suffer from neurological complications 
(similar to neuroborreliosis in animal models (Steere, 2001)), which can result in meningoencephalitis (Broderick et al., 1987; Oschmann et al., 1998).

\subsection{Rickettsiaceae: Scrub Typhus, Q Fever, Human Monocytic Ehrlichiosis, Rocky Mountain Spotted Fever and Colorado Tick Fever, and Epidemic Typhus}

Scrub Typhus, or tsutsugamushi disease, is caused by Orientia tsutsugamushi, grouped into a separate genus in the Rickettsiaceae family (Tamura et al., 1995; Perlman et al., 2006). The trombiculid mite vectors (Leptotrombidium deliense) feed on mice and humans in their chigger stage, or parasitic larval stage, which is responsible for the transmission of the bacterium. Vertical transmission is also possible (Traub \& Wisseman, 1974). The disease is endemic in a region, known as the 'tsutsugamushi triangle', ranging from Afghanistan, China, Korea, the islands of the southwestern Pacific, and northern Australia (Kelly et al., 2009) and encephalomyelitis was observed (Kim et al., 2000; Seong et al., 2001)

Query fever (commonly referred to as Q Fever) is a worldwide zoonosis caused by Coxiella burnetii, an obligatory intracellular organism which is a member of the family Rickettsiaceae, though genetic comparison revealed it is closer homology to Legionella pneumophila (Vogel, 2004; Parker et al., 2006). It enters the phagolysosome and later develops into the parasitophorous vacuole (PV), characterized by low $\mathrm{pH}$, acid hydrolases and cationic peptides (Voth \& Heinzen, 2007). These strange optimal conditions for growth make the culturing of this bacterium difficult (Omsland et al., 2009). Meningoencephalitis, though rare, is a potential complication of infection (Sawyer et al., 1987; Raoult et al., 2000). The bacterium is shed in large volumes during the birthing process (Welsh et al., 1958) and through milk production (Fishbein \& Raoult, 1992). Domesticated ruminants (cattle, sheep, goats) are the predominate bridge to human infection, making slaughterhouses workers, farmers and livestock researchers at the greatest risk for direct infection (McQuiston \& Childs, 2002), though it has been detected in other domestic and wild animals (Marrie et al., 1988; Buhariwalla et al., 1996; Stein \& Raoult, 1999). The bacterium can also be isolated from environmental samples where livestock reside (DeLay et al., 1950). Ticks are considered a reservoir, though not a disease vector (Mediannikov et al., 2010). There is also evidance of wind-blown induced infections of cites downwind of sheep farms (Tissot-Dupont et al., 1999).

Ehrlichia chaffeensis (Family Anaplasmataceae) is the causative agent for human monocytic ehrlichiosis (HME) (Dumler, Madigan et al. 2007). White tail deer (Odocoileus virginianus), rodents and other wildlife have been shown to harbor E. chaffeensis, which is transmitted to humans via Ixodes ticks (Amblyomma americanum) (Telford et al., 1996; Lockhart et al., 1997; Walls et al., 1998; A. A. Kocan, 2000; Varela-Stokes, 2007). Genera Ehrlichia does not undergo transovarial transmission, so the perpetuation of infected ticks is through horizontal transfer from mammals to ticks (Rikihisa, 2003). Encephalitis is a reported complication of the disease (Ratnasamy et al., 1996; Paddock \& Childs, 2003; Stone et al., 2004), which is found in the Atlantic, southeastern, and south central states (Paddock \& Childs, 2003).

Despite the name, Rocky Mountain Spotted Fever (RMSF) has been reported in at least 42 states and the District of Columbia (Treadwell et al., 2000). The lifecycle and transmission of $R$. rickettsii is primarily through transoverial. Infected female ticks give rise to infected eggs, which develop into infected larva/nymphs, which feed on small rodents and adults infect humans, an incidental host. Uninfected ticks can also feed on infected rodents to acquire the bacterium. Close contact during mating is also able to pass the virus (Walker, 1996 ). The main vectors for RMSF are the Dermacentor variabilis (American dog tick); in the northwestern US and Canada, and D. andersoni (Rocky Mountain Wood Tick) and the Lone Star Tick, 
Amblyomma americanum. In Latin America, Amblyomma cajennense (Cayenne Tick) is a human vector (Alderdice \& Burgess, 1998; Thorner et al., 1998; Treadwell et al., 2000; Dumler \& Walker, 2005). Meningoencephalitis can be a side effect of this disease (Horney \& Walker, 1988; Sexton \& Corey, 1992). To a smaller extent, Colorado Tick fever (CTF), transmitted by D. andersoni, manifested as meningoencephalitis in the past (Draughn et al., 1965).

Similar to RMSF and CTF, Rickettsia prowazekii is the causative agent of epidemic typhus, transmitted by the body louse (Pediculus humanus corporis). $R$ prowazekii is not carried in the saliva, rather excreted in the feces and present in ruptured lice remains, so open bite wounds, conjunctivae, and mucous membranes are pathways into the body (Andersson \& Andersson, 2000). Infection can still occur without a lice infestation through aerosols of fecal dust, which can maintain viable pathogens for several months (Raoult \& Roux, 1999). The lice themselves also succumb to the $R$. prowazekii infection, suffering from rupture of the infected epithelial cells and subsequent loss of blood, which is witnessed by the red color shift of the infected louse, and death within a week of infection (Houhamdi et al., 2002).

\section{Parasitic Encephalitis: Human African Trypanosomiasis, Schistosomiasis and Toxoplasmosis}

\subsection{Human African Trypanosomiasis: Trypanosoma brucei}

In humans, a Trypanosoma brucei infection results in Human African Trypanosomiasis, or sleeping sickness, of which the central nervous system becomes involved later in the disease onset (Kennedy, 2004; Bentivoglio et al., 2011). The blood-sucking tsetse fly (genus Glossina) is insect vector of Trypanosoma brucei gambiense, of which, humans are the parasitic reservoir. T.b. rhodesiense is a subspecies, and whose main reservoir is game animals and cattle, and results in an acute form of the disease (Bentivoglio et al., 2011). A bloodmeal from an infected animal starts the lifecycle of the trypanosomes. Procyclic trypomastigotes are ingested and multiply via binary fission in the fly's midgut cells. From there they travel through to the salivary glands and transform into epimastigotes then metacyclic trypomastigotes, which are capable of being transferred to a human host. The metacyclic trypomastigotes transform into trypomastigotes, are carried throughout the body and allowed to multiply in blood, lymph and spinal fluid (reviewed by Kennedy (2004)). Infection is usually fatal, but rare cases of recovery have been documented without chemotherapy treatment (Deborggraeve et al., 2008). A study done by Courtin et al. (2006) suggests that host genetics, specifically, single nucleotide polymorphisms in the IL10-592 A allele is associated with a lower risk of disease. A review done by Solano et al. (2010) of both tsetse fly genetics and genetic susceptibility of the host highlights the complexity of this disease.

\subsection{Schistosomiasis: Schistosoma}

Schistosomiasis (also called bilharzias) is caused by schistosomes, blood-dwelling fluke worms of the genus Schistosoma. Encephalitic onset is observed as Neuroschistosomiasis (Devine et al., 2008; Carod-Artal, 2010). Infection is worldwide, but is limited to areas conducive to maintaining the complex life cycle of the fluke, which involves a snail and human host and an aquatic environment to as passage between hosts. Eggs are released into waterway and hatch to form miracidia. These then penetrate the snail intermediate host. Sporocysts are formed, followed by cercariae, which can penetrate the human host, turning into schistosomulae. Adult worms reside in mesenteric venules. Once reproduction occurs, 
eggs move to either the intestine or ureters and are then released in the feces or urine respectively, completing the cycle and the means of egg release is species dependent (Cox, 2002). The main schistosomes infecting human are S. mansoni, S. haematobium, and S. japonicum and their respective snail hosts, Biomphalaria, Bulinus and Oncomelania. S. mansoni is found in Africa, the Arabian peninsula, and South America, with humans as its main host, but can also infect rodents and primates (as reviewed by (Gryseels et al., 2006; Brooker, 2010). The biodiversity of an area, as can the genetic diversity of a population, can play a role in the risk of human S. mansoni infection. Johnson et al. (2009) found when Biomphalaria glabrata was raised along with non-host snails, 60-80 per cent fewer cercariae were produced, resulting in a decreased risk of human infection.

\subsection{Toxoplasmosis: Toxoplasma gondii}

Toxoplasma gondii is responsible for toxoplasmosis, and cases of severe encephalitis have been reported, especially in immnocompromised individuals (i.e., transplant, AIDS and lymphatic cancer patients) (Frenhel et al., 1975; Araujo \& Remington, 1987; Luft \& Remington, 1992; Touahri et al., 2002; Derouin et al., 2008). As an obligate intracellular parasite, producing many asymptomatic infections, this parasite has balanced host immune detection and successful infection and reproduction and passage through blood-brain, placenta and intestinal barriers (Lambert \& Barragan, 2010). This phylum is named for the apical complex that assistants host cell infection (Lim \& McFadden, 2010). Although Family Felidae are the sole definitive host (allowing for sexual reproduction) (Hutchison, 1965), wide range of warm-blooded animals (including livestock) and birds can act as a intermediate host (Jacobs et al., 1960; Work, 1967; Tenter et al., 2000; Innes, 2010). Initial infection is through ingestion of raw or undercooked meat containing oocysts or live organisms (Jacobs et al., 1960) or through fecal matter contact (Dubey et al., 1970). Cysts are also persistent in the environment through a wide range of conditions (Frenkel et al., 1975), and after exposure to sodium hypochlorite or ozone (Wainwright et al., 2007). Infection can occur in three forms of the parasite: tachyzoites, bradyzoites found in cysts of infected tissue or the oocysts that are released in feces. Ingestion of cysts leads to rapid infection through the release of the bradyzoite in the digestive tract followed by integration into epithelial cells of the small intestine (Dubey, 1996). There are three strains of T. gondii. Type I is virulent with low genetic diversity, while Type II and III are distinct lineages and are nonvirulent (Sibley \& Boothroyd, 1992; Howe \& Sibley, 1995; Ajzenberg et al., 2004). The epigenetic mechanisms of these parasites have been investigated as a means of parasite physiology and potential therapeutics (Dixon et al., 2010).

\section{Conclusion}

The variety of encephalitic diseases mediated by arthropod and mammalian vectors, and requiring humans as a host in a parasitic lifestyle, is vast. With the advent of more sophisticated molecular technologies and a greater understanding of these diseases and their genetic codes, novel vaccines could be developed to help curb or prevent future infections (Seshadri et al., 2003; Diamond \& Mehlhop, 2008; Ertl, 2009). As genomes become available, a further characterization of phylogenetic relationships can be made (Mavarez et al., 2002; Bourhy et al., 2005; Jackson et al., 2010). PCR applications, including multiplex PCR (Paris et al., 2008), nested PCR (James et al., 2011), heteroduplex PCR (Lee et al., 2002), reverse transcriptase PCR and direct sequencing (Telford et al., 1997), restriction fragment 
length polymorphic analysis (Freylikhman et al., 2008), DNA microsatellite markers (Shrivastava et al., 2005) and microarray technology (Gobert et al., 2009; Omsland et al., 2009) will aid in the detection of the pathogens to a greater level of sensitivity and specificity than previously achieved. Aside from genetic advances, immunological based assays utilize antibody/antigen specificity to detection many pathogens (Enyaru et al., 2010). On the landscape scale, geospatial analysis of vector or reservoir migration may help understand the spread of these diseases (Eisen \& Eisen, 2011), as well as continued vigilance as cities and residential areas continue to sprawl further in the vector habitat (Alig et al., 2004; Estep et al., 2010; Matthews, 2011; Plowright et al., 2011). Research concerning vector control should also be expanded as a means of infection control (Solano et al., 2010). Climate change also has the potential to change the vector dynamics and should be considered when developing strategies to combat encephalitic diseases mediated by arthropod and mammalian vectors (Gubler et al., 2001; Lindgren \& Gustafson, 2001; Bi et al., 2003).

\section{References}

A. A. Kocan, G. C. L., L. C. Whitworth, G. L. Murphy, S. A. Ewing, and R. W. Barker (2000). Naturally occurring Ehrlichia chaffeensis infection in coyotes from Oklahoma. Emerging Infectious Diseases, Vol. 6, No. (5), pp. 477-480, 1080-6040

Ajzenberg, D., A. L. Bañuls, et al. (2004). Genetic diversity, clonality and sexuality in Toxoplasma gondii. International Journal for Parasitology, Vol. 34, No. (10), pp. 11851196, 0020-7519

Al Deeb, S. M., B. A. Yaqub, et al. (1989). Neurobrucellosis. Neurology, Vol. 39, No. (4), pp. 498-498, 0028-3878

Alderdice, J. M. and I. F. Burgess (1998). The travels of a lone star tick. Journal of Clinical Pathology, Vol. 51, No. (5), May, pp. 403-403, 0021-9746

Alexander H. K. and T. Day (2010). Risk factors for the evolutionary emergence of pathogens. J. R. Soc. Interface, Vol. 7, No. (51), pp. 1455-1474, 1742-5662

Alig, R. J., J. D. Kline, et al. (2004). Urbanization on the US landscape: looking ahead in the 21st century. Landscape and Urban Planning, Vol. 69, No. (2-3), pp. 219-234, 01692046

Allworth, A., K. Murray, et al. (1996). A case of encephalitis due to a lyssavirus recently identified in fruit bats. Commun Dis Intell, Vol. 20, No. (504), pp.,

Andersson, J. O. and S. G. E. Andersson (2000). A century of typhus, lice and Rickettsia. Research in Microbiology, Vol. 151, No. (2), pp. 143-150, 0923-2508

Antony, S. J. (1996). Leptospirosis - An Emerging Pathogen in Travel Medicine: A Review of its Clinical Manifestations and Management. Journal of Travel Medicine, Vol. 3, No. (2), pp. 113-118, 1708-8305

Araujo, F. G. and J. S. Remington (1987). Toxoplasmosis in immunocompromised patients. European Journal of Clinical Microbiology E Infectious Diseases, Vol. 6, No. (1), pp. 1-22, 0934-9723

Arguin, P. M., K. Murray-Lillibridge, et al. (2007). Serologic Evidence of Lyssavirus Infections among Bats, the Philippines. Emerging Infectious Diseases, Vol. 8, No. (3), pp. 258-262, 1080-6040 
Armstrong, P. M. and G. A. Theodore (2010). Eastern Equine Encephalitis Virus in Mosquitoes and Their Role as Bridge Vectors. Emerging Infectious Diseases, Vol. 16, No. (12), pp. 1869-1874, 1080-6059

Armstrong, R. W. and P. C. Fung (1993). Brainstem Encephalitis (Rhombencephalitis) Due to Listeria monocytogenes: Case Report and Review. Clinical Infectious Diseases, Vol. 16, No. (5), pp. 689-702, 1058-4838

Baillie, G. J., S. O. Kolokotronis, et al. (2008). Phylogenetic and evolutionary analyses of St. Louis encephalitis virus genomes. Molecular Phylogenetics and Evolution, Vol. 47, No. (2), pp. 717-728, 1055-7903

Barton, L. L. and N. J. Hyndman (2000). Lymphocytic Choriomeningitis Virus: Reemerging Central Nervous System Pathogen. Pediatrics, Vol. 105, No. (3), pp. e35-e35, 00314005

Barton, L. L. and M. B. Mets (2001). Congenital Lymphocytic Choriomeningitis Virus Infection: Decade of Rediscovery. Clinical infectious diseases, Vol. 33, No. (3), pp. 370374, 1058-4838

Barton, L. L., C. J. Peters, et al. (1995). Lymphocytic choriomeningitis virus: an unrecognized teratogenic pathogen. Emerging Infectious Diseases, Vol. 1, No. (4), pp. 152-153, 10806059

Becker, N., D. Petrić, et al. (2010). Medical Importance of Mosquitoes. Heidelberg, Springer.

Beja-Pereira, A., B. Bricker, et al. (2009). DNA Genotyping Suggests that Recent Brucellosis Outbreaks in the Greater Yellowstone Area Originated from Elk. Journal of Wildlife Diseases, Vol. 45, No. (4), October 1, 2009, pp. 1174-1177, 1943-3700

Bennett, N. (1976). Murray Valley encephalitis, 1974: clinical features. The Medical Journal of Australia, Vol. 2, No. (12), pp. 446-450, 0025-729X

Bentivoglio, M., R. Mariotti, et al. (2011). Neuroinflammation and brain infections: Historical context and current perspectives. Brain Research Reviews, Vol. 66, No. (1-2), pp. 152$173,0165-0173$

Bi, P., S. Tong, et al. (2003). Climate Variability and Transmission of Japanese Encephalitis in Eastern China. Vector-Borne and Zoonotic Diseases, Vol. 3, No. (3), pp. 111-115, 15303667

Bonthius, D. J. and S. Perlman (2007). Congenital Viral Infections of the Brain: Lessons Learned from Lymphocytic Choriomeningitis Virus in the Neonatal Rat. PLoS Pathogens, Vol. 3, No. (11), pp. e149, 2157-3999

Boromisa, R. D. and P. R. Grimstad (1986). Virus-Vector-Host Relationships of Aedes stimulans and Jamestown Canyon Virus in a Northern Indiana Enzootic Focus. American Journal of Tropical Medicine and Hygiene, Vol. 35, No. (6), pp. 1285-1295, 1476-1645

Bourhy, H., J. A. Cowley, et al. (2005). Phylogenetic relationships among rhabdoviruses inferred using the L polymerase gene. Journal of General Virology, Vol. 86, No. (10), October 1, 2005, pp. 2849-2858, 1465-2099

Bourhy, H., B. Kissi, et al. (1999). Ecology and evolution of rabies virus in Europe. Journal of General Virology, Vol. 80, No. (10), October 1, 1999, pp. 2545-2557, 1465-2099 
Briese, T., X.-Y. Jia, et al. (1999). Identification of a Kunjin/West Nile-like flavivirus in brains of patients with New York encephalitis. The Lancet, Vol. 354, No. (9186), pp. 1261$1262,0140-6736$

Broderick, J., B. Sandok, et al. (1987). Focal encephalitis in a young woman 6 years after the onset of Lyme disease: tertiary Lyme disease? Mayo Clinic Proceedings, Vol. 62, No. (4), pp. 313-316, 0025-6196

Brooker, S. (2010). Estimating the global distribution and disease burden of intestinal nematode infections: Adding up the numbers - A review. International Journal for Parasitology, Vol. 40, No. (10), pp. 1137-1144, 0020-7519

Broom, A. K., M. D. A. Lindsay, et al. (2002). Investigation of the Southern Limits of Murray Valley Encephalitis Activity in Western Australia During the 2000 Wet Season. Vector-Borne and Zoonotic Diseases, Vol. 2, No. (2), 2002/06/01, pp. 87-95, 1530-3667

Brown, R. N. and R. S. Lane (1992). Lyme disease in California: a novel enzootic transmission cycle of Borrelia burgdorferi. Science, Vol. 256, No. (5062), pp. 1439-1442, 0036-8075

Buhariwalla, F., B. Cann, et al. (1996). A Dog-Related Outbreak of Q Fever. Clinical Infectious Diseases, Vol. 23, No. (4), pp. 753-755, 1058-4838

Bulach, D. M., R. L. Zuerner, et al. (2006). Genome reduction in Leptospira borgpetersenii reflects limited transmission potential. Proceedings of the National Academy of Sciences, Vol. 103, No. (39), pp. 14560-14565, 1091-6490

Calisher, C. H. (1994). Medically important arboviruses of the United States and Canada. Clinical microbiology reviews, Vol. 7, No. (1), pp. 89-116, 0893-8512

Carod-Artal, F. J. (2010). Neuroschistosomiasis. Expert Review of Anti-Infective Therapy, Vol. 8, No. (11), pp. 1307-1318, 1478-7210

Chamberlain, R. W., R. K. Bikes, et al. (1954). Studies on the North American ArthropodBorne Encephalities. American Journal of Epidemiology, Vol. 60, No. (3), pp. 278-285, 1476-6256

Charrel, R., P. Gallian, et al. (2005). Emergence of Toscana virus in Europe. Emerging Infectious Diseases, Vol. 11, No. (11), pp. 1657-1663, 1080-6040

Chua, K., B. Chua, et al. (2002). Anthropogenic deforestation, El Niño and the emergence of Nipah virus in Malaysia. Malaysian Journal of Pathology, Vol. 24, No. (1), pp. 15-21, 0126-8635

Chua, K. B., C. Lek Koh, et al. (2002). Isolation of Nipah virus from Malaysian Island flyingfoxes. Microbes and Infection, Vol. 4, No. (2), pp. 145-151, 1286-4579

Cooper, L. A. and T. W. Scott (2001). Differential Evolution of Eastern Equine Encephalitis Virus Populations in Response to Host Cell Type. Genetics, Vol. 157, No. (4), pp. 1403-1412, 1943-2631

Courtin, D., L. Argiro, et al. (2006). Interest of tumor necrosis factor-alpha -308 G/A and interleukin-10 -592 C/A polymorphisms in human African trypanosomiasis. Infection, Genetics and Evolution, Vol. 6, No. (2), pp. 123-129, 1567-1348

Cox, F. E. G. (2002). History of human parasitology. Clinical microbiology reviews, Vol. 15, No. (4), Oct, pp. 595-612, 0893-8512 
Daubney, R., J. R. Hudson, et al. (1931). Enzootic hepatitis or rift valley fever. An undescribed virus disease of sheep cattle and man from east africa. The Journal of Pathology and Bacteriology, Vol. 34, No. (4), pp. 545-579, 1555-2039

de Jong, M. F., H. G. Rolan, et al. (2010). Innate immune encounters of the (Type) 4th kind: Brucella. Cellular Microbiology, Vol. 12, No. (9), Sep, pp. 1195-1202, 1462-5814

De Massis, F., A. Di Girolamo, et al. (2005). Correlation between animal and human brucellosis in Italy during the period 1997-2002. Clinical Microbiology and Infection, Vol. 11, No. (8), pp. 632-636, 1469-0691

Deborggraeve, S., M. Koffi, et al. (2008). Molecular analysis of archived blood slides reveals an atypical human Trypanosoma infection. Diagnostic Microbiology and Infectious Disease, Vol. 61, No. (4), pp. 428-433, 0732-8893

DeLay, P., E. Lennette, et al. (1950). Q fever in California; recovery of Coxiella burnetii from naturally-infected air-borne dust. Journal of Immunological, Vol. 65, No. (2), pp. 211220, 1550-6606

Derouin, F., H. Pelloux, et al. (2008). Prevention of toxoplasmosis in transplant patients. Clinical Microbiology and Infection, Vol. 14, No. (12), pp. 1089-1101, 1469-0691

Devine, M. J., P. A. Wilkinson, et al. (2008). Neuroschistosomiasis presenting as brainstem encephalitis. Neurology, Vol. 70, No. (23), Jun, pp. 2262-2264, 0028-3878

Diallo, M., J. Thonnon, et al. (1999). Vectors of Chikungunya virus in Senegal: current data and transmission cycles. American Journal of Tropical Medicine and Hygiene, Vol. 60, No. (2), pp. 281-286, 1476-1645

Diamond, M. S. and E. Mehlhop. (2008). The Molecular Basis of Antibody Protection Against West Nile Virus, In: Human Antibody Therapeutics for Viral Disease, S. K. Dessain, pp. (125-153), Springer Berlin Heidelberg, Retrieved from <http://dx.doi.org/10.1007/978-3-540-72146-8_5>

Dimopoulou, I., P. Politis, et al. (2002). Leptospirosis presenting with encephalitis-induced coma. Intensive Care Medicine, Vol. 28, No. (11), pp. 1682-1682-1682, 0342-4642

Dionisio, D., M. Valassina, et al. (2001). Encephalitis without Meningitis Due to Sandfly Fever Virus Serotype Toscana. Clinical Infectious Diseases, Vol. 32, No. (8), pp. 1241$1243,1058-4838$

Dixon, S. E., K. L. Stilger, et al. (2010). A decade of epigenetic research in Toxoplasma gondii. Molecular and Biochemical Parasitology, Vol. 173, No. (1), pp. 1-9, 0166-6851

Domingo, E. (1997). Rapid Evolution of Viral RNA Genomes. Journal of Nutrition, Vol. 127, No. (5), pp. 958S-961S, 1541-6100

Draughn, D. E., O. F. Sieber, et al. (1965). Colorado Tick Fever Encephalitis. Clinical Pediatrics, Vol. 4, No. (10), pp. 626-628, 0009-9228

Dubey, J. (1996). Toxoplasma Gondii, In: Medical Microbiology, S. Baron, The University of Texas Medical Branch at Galveston, Retrieved from http://www.ncbi.nlm.nih.gov/books/NBK7752/

Dubey, J. P., N. L. Miller, et al. (1970). The Toxoplasma gondii Oocyst from cat feces. The Journal of Experimental Medicine, Vol. 132, No. (4), pp. 636-662, 1540-9538

Dumler, J. S. and D. H. Walker (2005). Rocky Mountain Spotted Fever - Changing Ecology and Persisting Virulence. New England Journal of Medicine, Vol. 353, No. (6), pp. 551$553,1533-4406$ 
Ebel, G. D. (2009). Update on Powassan Virus: Emergence of a North American Tick-Borne Flavivirus. Annual Review of Entomology, Vol. 55, No. (1), 2010/01/01, pp. 95-110, 1545-4487

Eisen, L. and R. J. Eisen. (2011). Using Geographic Information Systems and Decision Support Systems for the Prediction, Prevention, and Control of Vector-Borne Diseases, In: Annual Review of Entomology, pp. (41-61), Annual Reviews, Retrieved from <<Go to ISI $>$ :/ / $000286841900003>$

Enyaru, J. C., J. O. Ouma, et al. (2010). Landmarks in the evolution of technologies for identifying trypanosomes in tsetse flies. Trends in Parasitology, Vol. 26, No. (8), pp. 388-394, 1471-4922

Epstein, J., H. Field, et al. (2006). Nipah virus: Impact, origins, and causes of emergence. Current Infectious Disease Reports, Vol. 8, No. (1), pp. 59-65, 1523-3847

Ertl, H. C. J. (2009). Novel Vaccines to Human Rabies. Plos Neglected Tropical Diseases, Vol. 3, No. (9), Sep, pp., 1935-2735

Erwin, P. C., T. F. Jones, et al. (2002). La Crosse Encephalitis in Eastern Tennessee: Clinical, Environmental, and Entomological Characteristics from a Blinded Cohort Study. American Journal of Epidemiology, Vol. 155, No. (11), pp. 1060-1065, 1476-6256

Estep, L. K., N. D. Burkett-Cadena, et al. (2010). Estimation of Dispersal Distances of Culex erraticus in a Focus of Eastern Equine Encephalitis Virus in the Southeastern United States. Journal of Medical Entomology, Vol. 47, No. (6), Nov, pp. 977-986, 0022-2585

Fishbein, D. B. and D. Raoult (1992). A Cluster of Coxiella Burnetii Infections Associated with Exposure to Vaccinated Goats and their Unpasteurized Dairy Products. American Journal of Tropical Medicine and Hygiene, Vol. 47, No. (1), July 1, 1992, pp. 35-40, 1476-1645

Flores, F. S., L. A. Diaz, et al. (2010). Vertical Transmission of St. Louis Encephalitis Virus in Culex quinquefasciatus (Diptera: Culicidae) in Córdoba, Argentina. Vector-Borne and Zoonotic Diseases, Vol. 10, No. (10), pp. 999-1002, 1530-3667

Fontenille, D., M. Traore-Lamizana, et al. (1994). First Isolations of Arboviruses from Phlebotomine Sand Flies in West Africa. American Journal of Tropical Medicine and Hygiene, Vol. 50, No. (5), pp. 570-574, 1476-1645

Foster, G., A. P. MacMillan, et al. (2002). A review of Brucella sp. infection of sea mammals with particular emphasis on isolates from Scotland. Veterinary Microbiology, Vol. 90, No. (1-4), pp. 563-580, 0378-1135

Frenhel, J. K., B. M. Nelson, et al. (1975). Immunosuppression and toxoplasmic encephalitis: Clinical and experimental aspects. Human Pathology, Vol. 6, No. (1), pp. 97-111, 0046-8177

Frenkel, J. K., A. Ruiz, et al. (1975). Soil Survival of Toxoplasma Oocysts in Kansas and Costa Rica. American Journal of Tropical Medicine and Hygiene, Vol. 24, No. (3), pp. 439-443, 1476-1645

Freylikhman, O. A., Y. A. Panfyorova, et al. (2008). Study of Heterogeneity of Coxiella burnettii Strains by Analysis of groEL Gene Restriction Fragment Length Polymorphism. Bulletin of Experimental Biology and Medicine, Vol. 146, No. (3), Sep, pp. $338-340,0007-4888$ 
Gandhi, M. and M. L. Chikindas (2007). Listeria: A foodborne pathogen that knows how to survive. International Journal of Food Microbiology, Vol. 113, No. (1), Jan, pp. 1-15, 0168-1605

Georgiev, V. S. (2009). Arthropod-Borne Viral Encephalitis, In: National Institute of Allergy and Infectious Diseases, NIH, V. S. Georgiev, pp. (151-162), Humana Press, Retrieved from <http://dx.doi.org/10.1007/978-1-60327-297-1_19>

Gholam, B. I. A., S. Puksa, et al. (1999). Powassan encephalitis: a case report with neuropathology and literature review. Canadian Medical Association Journal, Vol. 161, No. (11), pp. 1419-1422, 1488-2329

Gobert, G., L. Moertel, et al. (2009). Developmental gene expression profiles of the human pathogen Schistosoma japonicum. BMC Genomics, Vol. 10, No. (1), pp. 128, 1471-2164

Godfroid, J. (2002). Brucellosis in wildlife. Rev Sci Tech, Vol. 21, No. (2), pp. 277-286, 02531933

Grimstad, P. R., C. H. Calisher, et al. (1986). Jamestown Canyon Virus (California Serogroup) is the Etiologic Agent of Widespread Infection in Michigan Humans. American Journal of Tropical Medicine and Hygiene, Vol. 35, No. (2), pp. 376-386, 14761645

Grimstad, P. R., C. L. Shabino, et al. (1982). A Case of Encephalitis in a Human Associated with a Serologic Rise to Jamestown Canyon Virus. American Journal of Tropical Medicine and Hygiene, Vol. 31, No. (6), pp. 1238-1244, 1476-1645

Gryseels, B., K. Polman, et al. (2006). Human schistosomiasis. The Lancet, Vol. 368, No. (9541), pp. 1106-1118, 0140-6736

Gubler, D. J., P. Reiter, et al. (2001). Climate Variability and Change in the United States: Potential Impacts on Vector- and Rodent-Borne Diseases. Environmental Health Perspectives, Vol. 109, No., pp. 223-233, 0091-6765

Günther, G. and M. Haglund (2005). Tick-Borne Encephalopathies: Epidemiology, Diagnosis, Treatment and Prevention. Cns Drugs, Vol. 19, No. (12), pp. 1009-1032, 11727047

Gurav, Y. K., B. V. Tandale, et al. (2010). Chandipura virus encephalitis outbreak among children in Nagpur division, Maharashtra, 2007. Indian Journal of Medical Research, Vol. 132, No., pp. 395-399, 0971-5916

Ha, D. Q., C. H. Calisher, et al. (1995). Isolation of a Newly Recognized Alphavirus from Mosquitoes in Vietnam and Evidence for Human Infection and Disease. American Journal of Tropical Medicine and Hygiene, Vol. 53, No. (1), pp. 100-104, 1476-1645

Hall, R. A., A. K. Broom, et al. (1995). Immunodominant epitopes on the NS1 protein of MVE and KUN viruses serve as targets for a blocking ELISA to detect virus-specific antibodies in sentinel animal serum. Journal of Virological Methods, Vol. 51, No. (2-3), pp. 201-210, 0166-0934

Halpin, K., P. L. Young, et al. (2000). Isolation of Hendra virus from pteropid bats: a natural reservoir of Hendra virus. Journal of General Virology, Vol. 81, No. (8), pp. 1927-1932, 1465-2099

Hanna, J., I. Carney, et al. (2000). Australian bat lyssavirus infection: a second human case, with a long incubation period. Med J Aust., Vol. 172, No. (12), pp. 597-599, 
Hansen, W. and D. E. Docherty. (1999). Eastern Equine Encephalitis In: Field Manual of Wildlife Diseases: General Field Procedures and Diseases of Birds, M. Friend and J. C. Franson, pp. (171-174), US Department of the Interior, US Geological Survey, Retrieved from

Harcourt, B. H., A. Tamin, et al. (2000). Molecular Characterization of Nipah Virus, a Newly Emergent Paramyxovirus. Virology, Vol. 271, No. (2), pp. 334-349, 0042-6822

Harley, D., A. Sleigh, et al. (2001). Ross River Virus Transmission, Infection, and Disease: a Cross-Disciplinary Review. Clinical microbiology reviews, Vol. 14, No. (4), pp. 909932, 0893-8512

Hayes, C. G. (2001). West Nile Virus: Uganda, 1937, to New York City, 1999. Annals of the New York Academy of Sciences, Vol. 951, No. (1), pp. 25-37, 1749-6632

Horney, L. and D. Walker (1988). Meningoencephalitis as a Major Manifestation of Rocky Mountain Spotted Fever. Southern Medical Journal, Vol. 81, No. (7), pp. 915-918, 0038-4348

Houhamdi, L., P.-E. Fournier, et al. (2002). An Experimental Model of Human Body Louse Infection with Rickettsia prowazekii. Journal of Infectious Diseases, Vol. 186, No. (11), December 1, 2002, pp. 1639-1646, 1537-6613

Howe, D. K. and L. D. Sibley (1995). Toxoplasma gondii Comprises Three Clonal Lineages: Correlation of Parasite Genotype with Human Disease. Journal of Infectious Diseases, Vol. 172, No. (6), pp. 1561-1566, 1537-6613

Hughes, G. J., L. A. Orciari, et al. (2005). Evolutionary timescale of rabies virus adaptation to North American bats inferred from the substitution rate of the nucleoprotein gene. Journal of General Virology, Vol. 86, No. (5), May 1, 2005, pp. 1467-1474, 1465-2099

Hutchison, W. M. (1965). Experimental Transmission of Toxoplasma gondii. Nature, Vol. 206, No. (4987), pp. 961-962, 0028-0836

Innes, E. A. (2010). A Brief History and Overview of Toxoplasma gondii. Zoonoses and Public Health, Vol. 57, No. (1), Feb, pp. 1-7, 1863-1959

Jackson, A. P., M. Sanders, et al. (2010). The Genome Sequence of Trypanosoma brucei gambiense, Causative Agent of Chronic Human African Trypanosomiasis. Plos Neglected Tropical Diseases, Vol. 4, No. (4), pp. e658, 1935-2735

Jacobs, L., J. S. Remington, et al. (1960). A Survey of Meat Samples from Swine, Cattle, and Sheep for the Presence of Encysted Toxoplasma. The Journal of Parasitology, Vol. 46, No. (1), pp. 23-28, 0022-3395

James, M. C., R. W. Furness, et al. (2011). The importance of passerine birds as tick hosts and in the transmission of Borrelia burgdorferi, the agent of Lyme disease: a case study from Scotland. Ibis, Vol. 153, No. (2), Apr, pp. 293-302, 0019-1019

Johnson, M. and E. Colley (1969). Listeria monocytogenes encephalitis associated with corticosteroid therapy. Journal of Clinical Pathology, Vol. 22, No. (4), pp. 465-469, 1472-4146

Johnson, P. T. J., P. J. Lund, et al. (2009). Community diversity reduces Schistosoma mansoni transmission, host pathology and human infection risk. Proceedings of the Royal Society B: Biological Sciences, Vol. 276, No. (1662), pp. 1657-1663, 1471-2954

Kasari, T. R., D. A. Carr, et al. (2008). Evaluation of pathways for release of Rift Valley fever virus into domestic ruminant livestock, ruminant wildlife, and human populations 
in the continental United States. Javma-Journal of the American Veterinary Medical Association, Vol. 232, No. (4), Feb, pp. 514-529, 0003-1488

Kaufman, W. (2010). Ticks: Physiological aspects with implications for pathogen transmission. Ticks and Tick-borne Diseases, Vol. 1, No. (1), pp. 11-22, 1877-959X

Kelly, D. J., P. A. Fuerst, et al. (2009). Scrub Typhus: The Geographic Distribution of Phenotypic and Genotypic Variants of Orientia tsutsugamushi. Clinical Infectious Diseases, Vol. 48, No. (Supplement 3), pp. S203-S230, 1058-4838

Kennedy, P. G. E. (2004). Human African trypanosomiasis of the CNS: current issues and challenges. The Journal of Clinical Investigation, Vol. 113, No. (4), pp. 496-504, 00219738

Kim, D.-E., S.-H. Lee, et al. (2000). Scrub Typhus Encephalomyelitis With Prominent Focal Neurologic Signs. Archives of Neurology, Vol. 57, No. (12), pp. 1770-1772, 0375-8540

Kissi, B., H. Badrane, et al. (1999). Dynamics of rabies virus quasispecies during serial passages in heterologous hosts. Journal of General Virology, Vol. 80, No. (8), August 1, 1999, pp. 2041-2050, 1465-2099

Ko, A. I., C. Goarant, et al. (2009). Leptospira: the dawn of the molecular genetics era for an emerging zoonotic pathogen. Nature Reviews Microbiology, Vol. 7, No. (10), Oct, pp. 736-747, 1740-1526

Komar, N., D. J. Dohm, et al. (1999). Eastern equine encephalitis virus in birds: relative competence of European starlings (Sturnus vulgaris). American Journal of Tropical Medicine and Hygiene, Vol. 60, No. (3), pp. 387-391, 1476-1645

Krebs, J. W., M. L. Wilson, et al. (1995). Rabies: Epidemiology, Prevention, and Future Research. Journal of Mammalogy, Vol. 76, No. (3), pp. 681-694, 0022-2372

Kuno, G. and G. J. Chang (2005). Biological transmission of arboviruses: reexamination of and new insights into components, mechanisms, and unique traits as well as their evolutionary trends. Clinical microbiology reviews, Vol. 18, No. (4), pp. 608-637, $0893-$ 8512

Lahariya, C. and S. Pradhan (2006). Emergence of chikungunya virus in Indian subcontinent after 32 years: a review. Journal of vector borne diseases, Vol. 43, No., pp. 151-160, 1537-6591

Lambert, H. and A. Barragan (2010). Modelling parasite dissemination: host cell subversion and immune evasion by Toxoplasma gondii. Cellular Microbiology, Vol. 12, No. (3), Mar, pp. 292-300, 1462-5814

Lanciotti, R. S., J. T. Roehrig, et al. (1999). Origin of the West Nile Virus Responsible for an Outbreak of Encephalitis in the Northeastern United States. Science, Vol. 286, No. (5448), pp. 2333-2337, 0036-8075

Lane, R., J. Piesman, et al. (1991). Lyme borreliosis: relation of its causative agent to its vectors and hosts in North America and Europe. Annual Review of Entomology, Vol. 36, No., pp. 587, 1545-4487

Larsen, P., S. Chartrand, et al. (1993). Hydrocephalus complicating lymphocytic choriomeningitis virus infection. The Pediatric Infectious Disease Journal, Vol. 12, No.

(6), pp. 528-531, 0891-3668 
Laughlin, L. W., J. M. Meegan, et al. (1979). Epidemic Rift Valley fever in Egypt: observations of the spectrum of human illness. Transactions of the Royal Society of Tropical Medicine and Hygiene, Vol. 73, No. (6), pp. 630-633, 0035-9203

Lee, J. H., H. Hassan, et al. (2002). Identification of mosquito avian-derived blood meals by polymerase chain reaction-heteroduplex analysis. American Journal of Tropical Medicine and Hygiene, Vol. 66, No. (5), pp. 599-604, 1476-1645

Lim, L. and G. I. McFadden (2010). The evolution, metabolism and functions of the apicoplast. Philosophical Transactions of the Royal Society B-Biological Sciences, Vol. 365, No. (1541), Mar, pp. 749-763, 0962-8436

Lindgren, E. and R. Gustafson (2001). Tick-borne encephalitis in Sweden and climate change. The Lancet, Vol. 358, No. (9275), pp. 16-18, 0140-6736

Lingappa, J., T. Kuffner, et al. (2004). HLA-DQ6 and ingestion of contaminated water: possible gene-environment interaction in an outbreak of Leptospirosis. Genes and Immunity, Vol. 5, No. (3), pp. 197-202, 1466-4879

Lockhart, J. M., W. R. Davidson, et al. (1997). Isolation of Ehrlichia chaffeensis from wild white-tailed deer (Odocoileus virginianus) confirms their role as natural reservoir hosts. Journal of Clinical Microbiology, Vol. 35, No. (7), pp. 1681-1686, 1098-660X

Low, J. C. and W. Donachie (1997). A review of Listeria monocytogenes and listeriosis. Veterinary Journal, Vol. 153, No. (1), pp. 9-29, 1090-0233

Luft, B. J. and J. S. Remington (1992). Toxoplasmic Encephalitis in AIDS. Clinical Infectious Diseases, Vol. 15, No. (2), pp. 211-222, 1058-4838

Lum, L. C. S., S. K. Lam, et al. (1996). Dengue Encephalitis: A True Entity? American Journal of Tropical Medicine and Hygiene, Vol. 54, No. (3), pp. 256-259, 1476-1645

Madani, T. A., Y. Y. Al-Mazrou, et al. (2003). Rift Valley Fever Epidemic in Saudi Arabia: Epidemiological, Clinical, and Laboratory Characteristics. Clinical Infectious Diseases, Vol. 37, No. (8), pp. 1084-1092, 1058-4838

Mallewa, M., A. R. Fooks, et al. (2007). Rabies Encephalitis in Malaria-Endemic Area, Malawi, Africa. Emerging Infectious Diseases, Vol. 13, No. (1), pp. 136-139, 1080-6040

Marrie, T. J., H. Durant, et al. (1988). Exposure to Parturient Cats: A Risk Factor for Acquisition of Q Fever in Maritime Canada. Journal of Infectious Diseases, Vol. 158, No. (1), pp. 101-108, 1537-6613

Matthews, K. R. (2011). Controlling and Coordinating Development in Vector-Transmitted Parasites. Science, Vol. 331, No. (6021), Mar, pp. 1149-1153, 0036-8075

Mavale, M. S., G. Geevarghese, et al. (2005). Vertical and Venereal transmission of Chandipura Virus (Rhabdoviridae) by Aedes aegypti (Diptera: Culicidae). Journal of Medical Entomology, Vol. 42, No. (5), 2005/09/01, pp. 909-911, 0022-2585

Mavarez, J., C. Steiner, et al. (2002). Evolutionary history and phylogeography of the schistosome-vector freshwater snail Biomphalaria glabrata based on nuclear and mitochondrial DNA sequences. Heredity, Vol. 89, No. (4), pp. 266-272, 1365-2540

May, F. J., L. Li, et al. (2008). Genetic variation of St. Louis encephalitis virus. Journal of General Virology, Vol. 89, No. 8, pp. 1901-1910, 1465-2099

McJunkin, J. E., E. C. de los Reyes, et al. (2001). La Crosse Encephalitis in Children. New England Journal of Medicine, Vol. 344, No. (11), pp. 801-807, 1533-4406 
McLean, R. G., L. J. Kirk, et al. (1993). Avian Hosts of St. Louis Encephalitis Virus in Pine Bluff, Arkansas, 1991. American Journal of Tropical Medicine and Hygiene, Vol. 49, No. (1), pp. 46-52, 1476-1645

McLean, R. G., S. R. Ubico, et al. (2001). West Nile Virus Transmission and Ecology in Birds. Annals of the New York Academy of Sciences, Vol. 951, No. (1), pp. 54-57, 1749-6632

McQuiston, J. H. and J. E. Childs (2002). Q Fever in Humans and Animals in the United States. Vector-Borne and Zoonotic Diseases, Vol. 2, No. (3), pp. 179-191, 1530-3667

Mediannikov, O., F. Fenollar, et al. (2010). Coxiella burnetii in Humans and Ticks in Rural Senegal. Plos Neglected Tropical Diseases, Vol. 4, No. (4), pp. e654, 1935-2735

Messenger, S. L., J. S. Smith, et al. (2002). Emerging Epidemiology of Bat-Associated Cryptic Cases of Rabies in Humans in the United States. Clinical Infectious Diseases, Vol. 35, No. (6), September 15, 2002, pp. 738-747, 1058-4838

Mohd Nor, M. N., C. H. Gan, et al. (2000). Nipah virus infection of pigs in peninsular Malaysia. Revue scientifique et technique (International Office of Epizootics), Vol. 19, No. (1), pp. 160-165, 0253-1933

Moreno, E., A. Cloeckaert, et al. (2002). Brucella evolution and taxonomy. Veterinary Microbiology, Vol. 90, No. (1-4), pp. 209-227, 0378-1135

Morimoto, K., D. C. Hooper, et al. (1998). Rabies virus quasispecies: Implications for pathogenesis. Proceedings of the National Academy of Sciences, Vol. 95, No. (6), March 17, 1998, pp. 3152-3156, 1091-6490

Muzaffar, J., P. Venkata Krishnan, et al. (2006). Dengue encephalitis: why we need to identify this entity in a dengue-prone region. Singapore Med Journal, Vol. 47, No. (11), pp. 975-957, 0037-5675

Narasimha Rao, S., N. S. Wairagkar, et al. (2008). Brain Stem Encephalitis Associated with Chandipura in Andhra Pradesh Outbreak. Journal of Tropical Pediatrics, Vol. 54, No. (1), February 1, 2008, pp. 25-30, 0142-6338

O'Sullivan, J. D., A. M. Allworth, et al. (1997). Fatal encephalitis due to novel paramyxovirus transmitted from horses. The Lancet, Vol. 349, No. (9045), pp. 93-95, 0140-6736

Omsland, A., D. C. Cockrell, et al. (2009). Host cell-free growth of the Q fever bacterium Coxiella burnetii. Proceedings of the National Academy of Sciences, Vol. 106, No. (11), pp. 4430-4434, 1091-6490

Orsi, R., Q. Sun, et al. (2008). Genome-wide analyses reveal lineage specific contributions of positive selection and recombination to the evolution of Listeria monocytogenes. BMC Evol Biol, Vol. 8, No., pp. 233, 1471-2148

Oschmann, P., W. Dorndorf, et al. (1998). Stages and syndromes of neuroborreliosis. Journal of Neurology, Vol. 245, No. (5), pp. 262-272, 0340-5354

Paddock, C. D. and J. E. Childs (2003). Ehrlichia chaffeensis: a Prototypical Emerging Pathogen. Clinical microbiology reviews, Vol. 16, No. (1), pp. 37-64, 0893-8512

Pappas, G., P. Papadimitriou, et al. (2008). The globalization of leptospirosis: worldwide incidence trends. International Journal of Infectious Diseases, Vol. 12, No. (4), Jul, pp. 351-357, 1201-9712

Paredes, A., S. Weaver, et al. (2005). Structural biology of old world and new world alphaviruses, In: Infectious Diseases from Nature: Mechanisms of Viral Emergence and 
Persistence, C. J. Peters and C. H. Calisher, pp. (179-185), Springer Vienna, Retrieved from <http://dx.doi.org/10.1007/3-211-29981-5_14>

Paris, D. H., S. D. Blacksell, et al. (2008). Real-time multiplex PCR assay for detection and differentiation of rickettsiae and orientiae. Transactions of the Royal Society of Tropical Medicine and Hygiene, Vol. 102, No. (2), pp. 186-193, 0035-9203

Parker, N. R., J. H. Barralet, et al. (2006). Q fever. The Lancet, Vol. 367, No. (9511), pp. 679688, 0140-6736

Pastorino, B., J. J. Muyembe-Tamfum, et al. (2004). Epidemic resurgence of Chikungunya virus in democratic Republic of the Congo: Identification of a new central African strain. Journal of Medical Virology, Vol. 74, No. (2), pp. 277-282, 1096-9071

Paton, N. I., Y. S. Leo, et al. (1999). Outbreak of Nipah-virus infection among abattoir workers in Singapore. The Lancet, Vol. 354, No. (9186), pp. 1253-1256, 0140-6736

Pepin, M., M. Bouloy, et al. (2010). Rift Valley fever virus (Bunyaviridae: Phlebovirus): an update on pathogenesis, molecular epidemiology, vectors, diagnostics and prevention. Veterinary Research, Vol. 41, No. (6), pp., 1297-9716

Perlman, S. J., M. S. Hunter, et al. (2006). The emerging diversity of Rickettsia. Proceedings of the Royal Society B: Biological Sciences, Vol. 273, No. (1598), pp. 2097-2106, 1471-2954

Pfeffer, M. and G. Dobler (2010). Emergence of zoonotic arboviruses by animal trade and migration. Parasites \& Vectors, Vol. 3, No. (1), pp. 1-15, 1756-3305

Pfeffer, M. and G. Dobler (2010). Emergence of zoonotic arboviruses by animal trade and migration. Parasites \& Vectors, Vol. 3, No. (35), pp., 1756-3305

Plowright, R., P. Foley, et al. (2011). Urban Habituation, Connectivity, and Stress Synchrony: Hendra Virus Emergence from Flying Foxes (Pteropus spp.). EcoHealth, Vol. 7, No., pp. S36-S37 1612-9202

Plowright, R. K., H. E. Field, et al. (2008). Reproduction and nutritional stress are risk factors for Hendra virus infection in little red flying foxes (Pteropus scapulatus). Proceedings of the Royal Society B: Biological Sciences, Vol. 275, No. (1636), pp. 861-869, 1091-6490

Potharaju, N. R. and A. K. Potharaju (2006). Is Chandipura virus an emerging human pathogen? Archives of Disease in Childhood, Vol. 91, No. (3), pp. 279-280, 1468-2044

Rajapakse, S., C. Rodrigo, et al. (2010). Atypical manifestations of chikungunya infection. Transactions of the Royal Society of Tropical Medicine and Hygiene, Vol. 104, No. (2), pp. 89-96, 0035-9203

Rampal, M. Sharda, et al. (2007). Neurological complications in Chikungunya fever. Journal of Association of Physicians of India, Vol. 55, No., pp. 765-769, 0004-5772

Rao, B. L., A. Basu, et al. (2004). A large outbreak of acute encephalitis with high fatality rate in children in Andhra Pradesh, India, in 2003, associated with Chandipura virus. The Lancet, Vol. 364, No. (9437), pp. 869-874, 0140-6736

Raoult, D. and V. Roux (1999). The body louse as a vector of reemerging human diseases. Clinical Infectious Diseases, Vol. 29, No. (4), pp. 888-911, 1058-4838

Raoult, D., H. Tissot-Dupont, et al. (2000). Q Fever 1985-1998: Clinical and Epidemiologic Features of 1,383 Infections. Medicine, Vol. 79, No. (2), pp. 109-123, 0025-7974

Ratnasamy, N., E. D. Everett, et al. (1996). Central Nervous System Manifestations of Human Ehrlichiosis. Clinical Infectious Diseases, Vol. 23, No. (2), pp. 314-319, 10584838 
Rikihisa, Y. (2003). Mechanisms to Create a Safe Haven by Members of the Family Anaplasmataceae. Annals of the New York Academy of Sciences, Vol. 990, No. (1), pp. 548-555, 1749-6632

Roberts, A. J. and M. Wiedmann (2003). Pathogen, host and environmental factors contributing to the pathogenesis of listeriosis. Cellular and Molecular Life Sciences, Vol. 60, No. (5), May, pp. 904-918, 1420-682X

Robin, S., D. Ramful, et al. (2008). Neurologic Manifestations of Pediatric Chikungunya Infection. Journal of Child Neurology, Vol. 23, No. (9), pp. 1028-1035, 1708-8828

Russell, R. C. and D. E. Dwyer (2000). Arboviruses associated with human disease in Australia. Microbes and Infection, Vol. 2, No. (14), pp. 1693-1704, 1286-4579

Rust, R. S., W. H. Thompson, et al. (1999). Topical Review: La Crosse and Other Forms of California Encephalitis. Journal of Child Neurology, Vol. 14, No. (1), pp. 1-14, 17088828

Salah, U., J. Hossain, et al. (2011). Use of Infrared Camera to Understand Bats' Access to Date Palm Sap: Implications for Preventing Nipah Virus Transmission. EcoHealth, Vol., No., pp. 1-9, 1612-9202

Sawyer, L. A., D. B. Fishbein, et al. (1987). Q Fever: Current Concepts. Reviews of Infectious Diseases, Vol. 9, No. (5), pp. 935-946, 0162-0886

Scott, T. W. (1988). Vertebrate host ecology, In: The arboviruses: epidemiology and ecology, T. P. Monath, pp. (257-280), CRC Press,

Seong, S., M.-S. Choi, et al. (2001). Orientia tsutsugamushi infection:overview and immune responses. Microbes and Infection, Vol. 3, No. (1), pp. 11-21, 1286-4579

Seshadri, R., I. T. Paulsen, et al. (2003). Complete genome sequence of the Q-fever pathogen Coxiella burnetii. Proceedings of the National Academy of Sciences, Vol. 100, No. (9), pp. 5455-5460, 1091-6490

Sexton, D. J. and G. R. Corey (1992). Rocky Mountain "Spotless" and "Almost Spotless" Fever: A Wolf in Sheep's Clothing. Clinical Infectious Diseases, Vol. 15, No. (3), pp. 439-448, 1058-4838

Shakir, R. A., A. S. N. Al-Din, et al. (1987). Clinical categories of neurobrucellosis. A report on 19 cases. Brain, Vol. 110, No. (1), pp. 213-223, 1460-2156

Shrivastava, J., B. Z. Qian, et al. (2005). An insight into the genetic variation of Schistosoma japonicum in mainland China using DNA microsatellite markers. Molecular Ecology, Vol. 14, No. (3), pp. 839-849, 1365-294X

Sibley, L. D. and J. C. Boothroyd (1992). Virulent strains of Toxoplasma gondii comprise a single clonal lineage. Nature, Vol. 359, No. (6390), pp. 82-85, 0028-0836

Smith, J. S., L. A. Orciari, et al. (1995). Molecular epidemiology of rabies in the United States. Seminars in Virology, Vol. 6, No. (6), pp. 387-400, 1044-5773

Solano, P., S. Ravel, et al. (2010). How can tsetse population genetics contribute to African trypanosomiasis control? Trends in Parasitology, Vol. 26, No. (5), pp. 255-263, 14714922

Solomon, T., M. H. Ooi, et al. (2003). West Nile encephalitis. BMJ, Vol. 326, No. (7394), pp. 865-869, 1756-1833 
Spielman, A., J. M. C. Ribeiro, et al. (1987). Dissemination and salivary delivery of Lyme disease spirochetes in vector ticks (Acari: Ixodidae). Journal of Medical Entomology, Vol. 24, No., pp. 201-205, 0022-2585

Steere, A. C. (2001). Lyme Disease. New England Journal of Medicine, Vol. 345, No. (2), pp. 115$125,1533-4406$

Stein, A. and D. Raoult (1999). Pigeon Pneumonia in Provence: A Bird-Borne Q Fever Outbreak. Clinical Infectious Diseases, Vol. 29, No. (3), pp. 617-620, 1058-4838

Stone, J. H., K. Dierberg, et al. (2004). Human Monocytic Ehrlichiosis. JAMA: The Journal of the American Medical Association, Vol. 292, No. (18), pp. 2263-2270, 0098-7484

Sudia, W. D., V. Newhouse, et al. (1969). Venezuelan equine encephalitis virus-vector studies following a human case in Dade County, Florida. Mosquito News Vol. 29, No., pp. 596-600, 0027-142X

Swaminathan, B. and P. Gerner-Smidt (2007). The epidemiology of human listeriosis. Microbes and Infection, Vol. 9, No. (10), pp. 1236-1243, 1286-4579

Tamura, A., N. Ohashi, et al. (1995). Classification of Rickettsia tsutsugamushi in a New Genus, Orientia gen. nov., as Orientia tsutsugamushi comb. nov. International Journal of Systematic Bacteriology, Vol. 45, No. (3), pp. 589-591, 0020-7713

Tan, L. V., D. Q. Ha, et al. (2008). Me Tri virus: a Semliki Forest virus strain from Vietnam? Journal of General Virology, Vol. 89, No. (9), pp. 2132-2135, 1465-2099

Taylor, L. H., S. M. Latham, et al. (2001). Risk factors for human disease emergence. Philosophical Transactions of the Royal Society of London. Series B: Biological Sciences, Vol. 356, No. (1411), pp. 983-989, 0962-8436

Telford, S. R., P. M. Armstrong, et al. (1997). A new tick-borne encephalitis-like virus infecting New England deer ticks, Ixodes dammini. Emerging Infectious Diseases, Vol. 3, No. (2), pp. 165-170, 1080-6059

Telford, S. R., J. E. Dawson, et al. (1996). Perpetuation of the agent of human granulocytic ehrlichiosis in a deer tick-rodent cycle. Proceedings of the National Academy of Sciences, Vol. 93, No. (12), pp. 6209-6214, 1091-6490

Tenter, A. M., A. R. Heckeroth, et al. (2000). Toxoplasma gondii: from animals to humans. International Journal for Parasitology, Vol. 30, No. (12-13), pp. 1217-1258, 0020-7519

Thorner, A. R., D. H. Walker, et al. (1998). Rocky Mountain Spotted Fever. Clinical Infectious Diseases, Vol. 27, No. (6), pp. 1353-1360, 1058-4838

Tissot-Dupont, H., S. Torres, et al. (1999). Hyperendemic focus of Q fever related to sheep and wind. American Journal of Epidemiology, Vol. 150, No. (1), pp. 67-74, 1476-6256

Touahri, T., M. Pulik, et al. (2002). Toxoplasmic Encephalitis in a Non-HIV Patient With Follicular Lymphoma. International Journal of Hematology, Vol. 75, No. (1), pp. 111$112-112,0925-5710$

Traub, R. and C. L. Wisseman (1974). The Ecology of Chigger-Borne Rickettsiosis (Scrub Typhus). Journal of Medical Entomology, Vol. 11, No., pp. 237-303, 0022-2585

Treadwell, T. A., R. C. Holman, et al. (2000). Rocky Mountain spotted fever in the United States, 1993-1996. American Journal of Tropical Medicine and Hygiene, Vol. 63, No. (1), pp. 21-26, 1476-1645

Valassina, M., M. Cusi, et al. (2003). A Mediterranean arbovirus: The Toscana virus. Journal of NeuroVirology, Vol. 9, No., pp. 577-583, 1538-2443 
Valassina, M., M. Valentini, et al. (2003). Serological Survey of Toscana Virus Infections in a High-Risk Population in Italy. Clinical and Vaccine Immunology, Vol. 10, No. (3), pp. 483-484, 1556-679X

Van Ranst, M. (2004). Chandipura virus: an emerging human pathogen? The Lancet, Vol. 364, No. (9437), pp. 821-822, 0140-6736

Varela-Stokes, A. S. (2007). Transmission of Ehrlichia chaffeensis from lone star ticks (Amblyomma americanum) to white-tailed deer (Odocoileus virginianus). Journal of Wildlife Diseases, Vol. 43, No. (3), July 1, 2007, pp. 376-381, 1943-3700

Vincent P. Hsu, M. J. H., † Umesh D. Parashar,* Mohammed Monsur Ali,‡ Thomas G. Ksiazek, ${ }^{*}$ Ivan Kuzmin, ${ }^{*}$ Michael Niezgoda, ${ }^{*}$ Charles Rupprecht, ${ }^{*}$ Joseph Bresee, ${ }^{*}$ and Robert F. Breiman† (2004). Nipah virus encephalitis reemergence, Bangladesh. Emerging Infectious Diseases, Vol. 10, No. (12), pp., 1080-6040

Vogel, J. P. (2004). Turning a tiger into a house cat: using Legionella pneumophila to study Coxiella burnetii. Trends in Microbiology, Vol. 12, No. (3), pp. 103-105, 0966-842X

Voth, D. E. and R. A. Heinzen (2007). Lounging in a lysosome: the intracellular lifestyle of Coxiella burnetii. Cellular Microbiology, Vol. 9, No. (4), pp. 829-840, 1462-5822

Wainwright, K. E., M. A. Miller, et al. (2007). Chemical Inactivation of Toxoplasma gondii Oocysts in Water. The Journal of Parasitology, Vol. 93, No. (4), pp. 925-931, 0022-3395

Walker, D. (1996 ). Rickettsiae, In: Medical Microbiology, B. Baron, pp. University of Texas Medical Branch at Galveston, Retrieved from

Walls, J. J., K. M. Asanovich, et al. (1998). Serologic Evidence of a Natural Infection of WhiteTailed Deer with the Agent of Human Granulocytic Ehrlichiosis in Wisconsin and Maryland. Clinical and Vaccine Immunology, Vol. 5, No. (6), pp. 762-765, 1556-679X

Wang, L.-F., J. S. Mackenzie, et al. (2008). Disease Outbreaks Caused by Emerging Paramyxoviruses of Bat Origin, In: Emerging Infections in Asia, Y. Lu, M. Essex and B. Roberts, pp. (193-208), Springer US, Retrieved from <http://dx.doi.org/10.1007/978-0-387-75722-3_12>

Warrilow, D., I. L. Smith, et al. (2002). Sequence Analysis of an Isolate from a Fatal Human Infection of Australian Bat Lyssavirus. Virology, Vol. 297, No. (1), pp. 109-119, 00426822

Weaver, S. C. and A. D. T. Barrett (2004). Transmission cycles, host range, evolution and emergence of arboviral disease. Nature Reviews Microbiology, Vol. 2, No. (10), pp. 789-801, 1740-1526

Weaver, S. C., A. C. Brault, et al. (1999). Genetic and Fitness Changes Accompanying Adaptation of an Arbovirus to Vertebrate and Invertebrate Cells. The Journal of Virology, Vol. 73, No. (5), pp. 4316-4326, 1465-2099

Weaver, S. C., C. Ferro, et al. (2004). Venezuelan Equine Encephalitis. Annual Review of Entomology, Vol. 49, No. (141-174), pp., 1545-4487

Weaver, S. C., W. Kang, et al. (1997). Recombinational history and molecular evolution of western equine encephalomyelitis complex alphaviruses. The Journal of Virology, Vol. 71, No. (1), pp. 613-623, 1465-2099

Weaver, S. C., T. W. Scott, et al. (1991). Molecular evolution of eastern equine encephalomyelitis virus in North America. Virology, Vol. 182, No. (2), pp. 774-784, 0042-6822 
Welsh, H. H., E. H. Lennette, et al. (1958). Air-borne transmission of Q fever: the role of parturition in the generation of infective aerosols. Annals of the New York Academy of Sciences, Vol. 70, No. (3), pp. 528-540, 1749-6632

WHO. Dengue and dengue haemorrhagic fever, In: Media centre Available from: <http://www.who.int/mediacentre/factsheets/fs117/en/>

Williamson, M. M., P. T. Hooper, et al. (2000). Experimental Hendra Virus Infectionin Pregnant Guinea-pigs and Fruit Bats (Pteropus poliocephalus). Journal of Comparative Pathology, Vol. 122, No. (2-3), pp. 201-207, 0021-9975

Work, K. (1967). Isolation of Toxoplasma Gondii from the flesh of sheep, swine and cattle. Acta Pathologica Microbiologica Scandinavica, Vol. 71, No. (2), pp. 296-306, 1600-0463

Zacks, M. A. and S. Paessler (2010). Encephalitic alphaviruses. Veterinary Microbiology, Vol. 140, No. (3-4), pp. 281-286, 0378-1135

Zamparo, J. M., T. G. Andreadis, et al. (1997). Serologic evidence of Jamestown Canyon virus infection in white-tailed deer populations from Connecticut. Journal of Wildlife Diseases, Vol. 33, No. (3), pp. 623-627, 1943-3700 


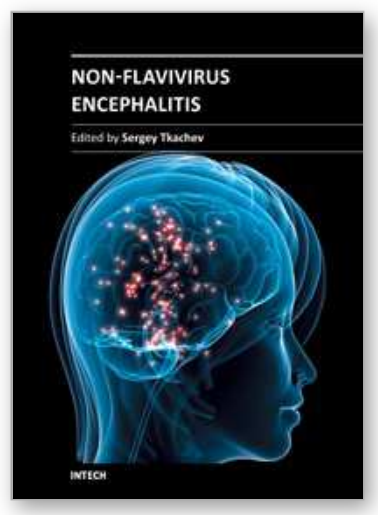

\author{
Non-Flavivirus Encephalitis \\ Edited by Dr. Sergey Tkachev
}

ISBN 978-953-307-720-8

Hard cover, 360 pages

Publisher InTech

Published online 16, November, 2011

Published in print edition November, 2011

This book covers the different aspects of non-flavivirus encephalitises of different ethiology. The first section of the book considers general problems of epidemiology such as study of zoonotic and animal vectors of encephalitis causative agents and methods and approaches for encephalitis zoonoses investigations. The members of different virus species are known to be the causative agents of encephalitis, so the second section of the book is devoted to these viral pathogens, their epidemiology, pathology, diagnostics and molecular mechanisms of encephalitis development by such viruses as HIV/SIV, herpes simplex virus type 1 and equine herpesvirus 9, measles virus, coronaviruses, alphaviruses and rabies virus. The next section of the book concerns the study of protozoan pathogens such as toxoplasma and amoebae. The last section of the book is devoted to multicellular pathogen as human Filaria Loa Loa - a filarial worm restricted to the West Africa.

\title{
How to reference
}

In order to correctly reference this scholarly work, feel free to copy and paste the following:

Colleen Mikelson and Sean Richards (2011). Zoonotic and Animal Vector Mediated Encephalitides, NonFlavivirus Encephalitis, Dr. Sergey Tkachev (Ed.), ISBN: 978-953-307-720-8, InTech, Available from: http://www.intechopen.com/books/non-flavivirus-encephalitis/zoonotic-and-animal-vector-mediatedencephalitides

\section{INTECH}

open science | open minds

\author{
InTech Europe \\ University Campus STeP Ri \\ Slavka Krautzeka 83/A \\ 51000 Rijeka, Croatia \\ Phone: +385 (51) 770447 \\ Fax: +385 (51) 686166 \\ www.intechopen.com
}

\author{
InTech China \\ Unit 405, Office Block, Hotel Equatorial Shanghai \\ No.65, Yan An Road (West), Shanghai, 200040, China \\ 中国上海市延安西路65号上海国际贵都大饭店办公楼 405 单元 \\ Phone: +86-21-62489820 \\ Fax: +86-21-62489821
}


(C) 2011 The Author(s). Licensee IntechOpen. This is an open access article distributed under the terms of the Creative Commons Attribution 3.0 License, which permits unrestricted use, distribution, and reproduction in any medium, provided the original work is properly cited. 